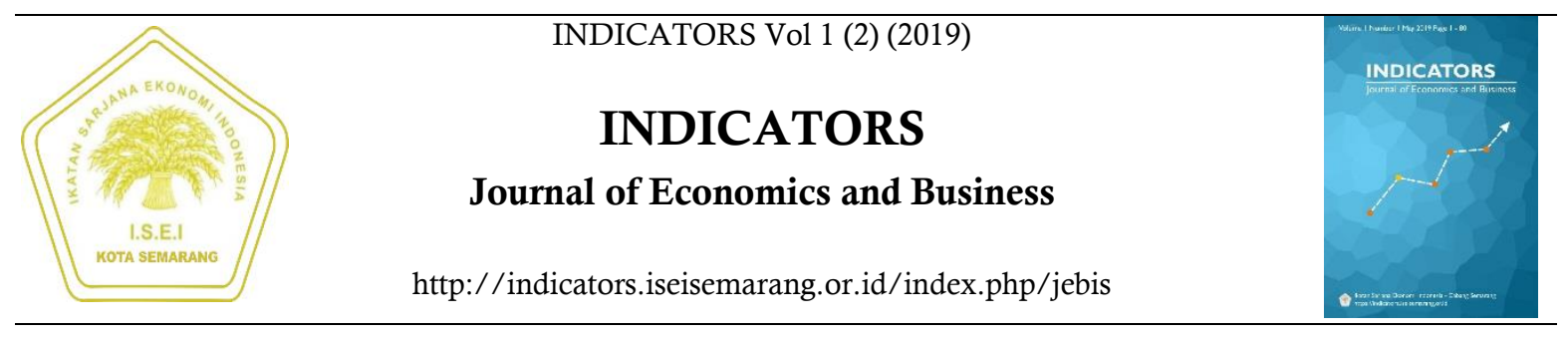

\title{
DAMPAK SPILLOVER PEKERJA MIGRAN INDONESIA (PMI) ASAL JAWA TENGAH TERHADAP PERTUMBUHAN EKONOMI PROPINSI JAWA TENGAH
}

\author{
Caroline $^{1)}$, FX Sugiyanto ${ }^{2) 凶}$, Achmad Syakir Kurnia $^{3)}$, Etty Puji Lestari ${ }^{4)}$, Ceacilia Srimindarti ${ }^{5)}$ \\ ${ }^{1}$ Fakultas Ekonomi dan Ilmu Sosial, Universitas Sultan Fatah \\ ${ }^{2,3}$ Fakultas Ekonomika dan Bisnis, Universitas Diponegoro \\ ${ }^{4}$ Fakultas Ekonomi, Universitas Terbuka \\ ${ }^{5}$ Fakultas Ekonomi, Universitas Stikubank
}

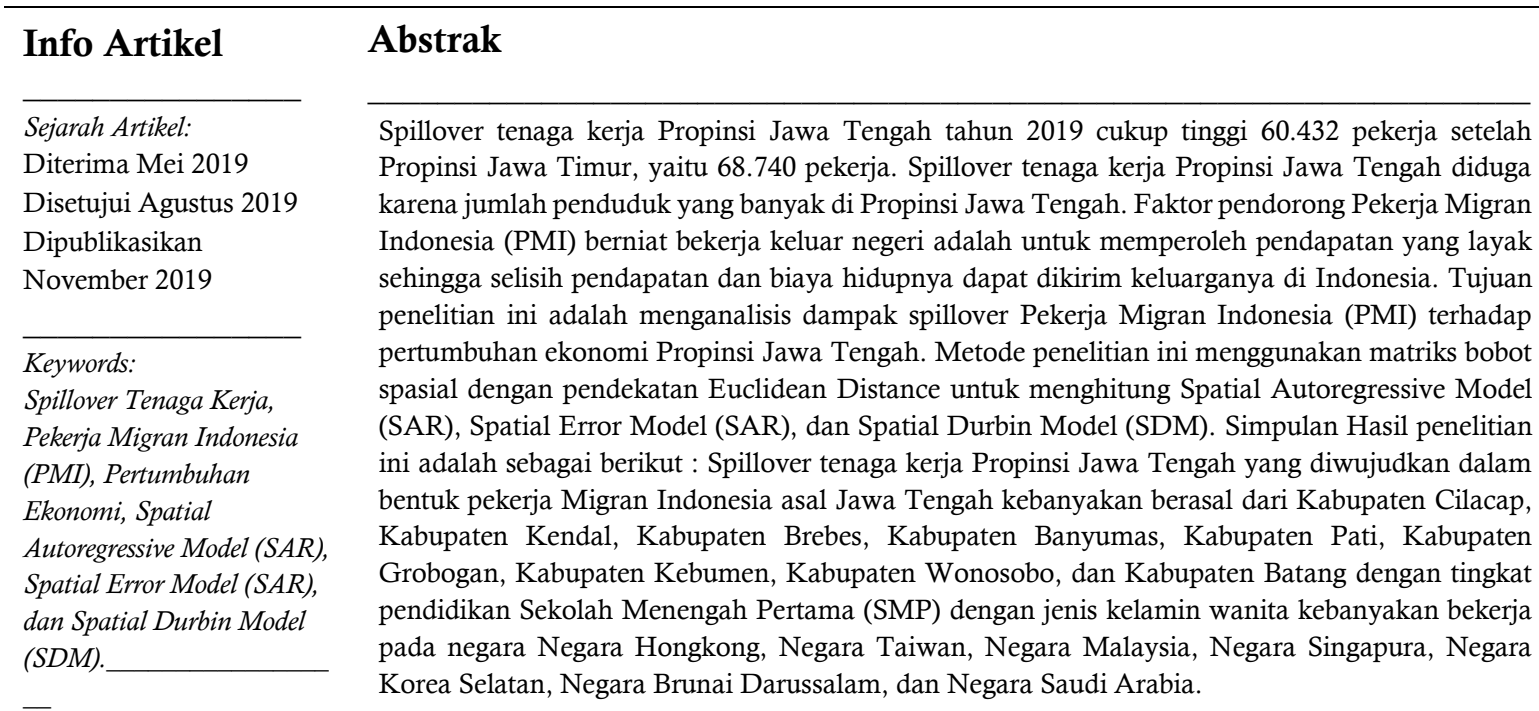

\footnotetext{
${ }^{\square}$ Alamat korespondensi:

Fakultas Ekonomika dan Bisnis, Universitas Diponegoro

J1. H.Prof. Soedarto, SH

E-mail: (fx.sugiyanto09@gmail.com)
} 


\section{PENDAHULUAN}

Spillover tenaga kerja Propinsi Jawa Tengah dalam bentuk migrasi tenaga kerja yang bekerja keluar negeri mulai jelas terlihat setelah adanya bentuk kerjasama Masyarakat Ekonomi ASEAN pada awal 2015 dengan adanya kesepakatan mobilitas tenaga kerja antar negara anggota ASEAN. Jumlah Pekerja Migran Indonesia (PMI) di Propinsi Jawa Tengah terbilang banyak jumlahnya setelah jumlah PMI
Propinsi Jawa Timur. Gambar 1. Menampakkan jumlah Pekerja Migran Indonesia (PMI) Jawa Tengah diatas Propinsi Jawa Barat, Propinsi Banten, Propinsi DI Yogyakarta, dan Propinsi DKI Jakarta. Jumlah Pekerja Migran Indonesia (PMI) Jawa Tengah tahun 2019 mengalami penenurunan dari tahun 2018, yaitu semula tahun 2018 Pekerja Migran Indonesia (PMI) Jawa Tengah 61.434 pekerja menjadi 60.432 pekerja di tahun 2019.

Gambar 1

Jumlah Pekerja Migran Indonesia (PMI) Tahun 2017-2019 (Pekerja)

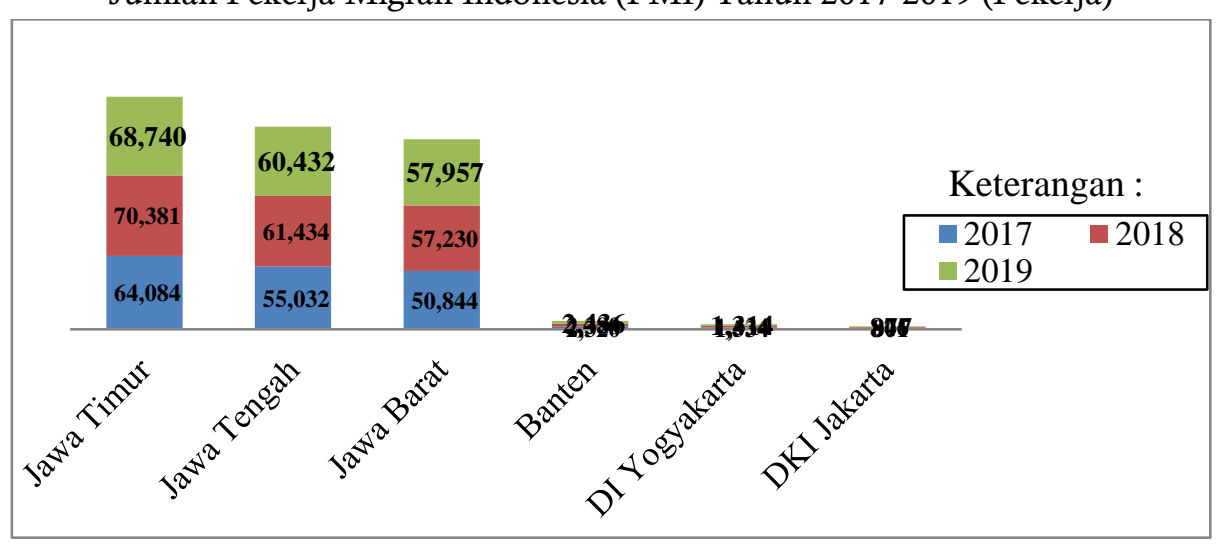

Sumber : https://bp2mi.go.id/statistik-detail/data-penempatan-dan-perlindungan-tkiperiode-tahun-2019, diolah

Faktor pertumbuhan ekonomi ada kaitannya dengan Pekerja Migran Indonesia (PMI) Jawa Tengah. Pekerja Migran Indonesia (PMI) Jawa Tengah yang bekerja diluar negeri akan mengirim uang ke sanak keluarganya yang tinggal di Indonesia dalam bentuk remitansi. Masuknya remitansi dari Pekerja Migran Indonesia (PMI) Jawa Tengah ke Indonesia akan menjadi sumber pendapatan daerah Propinsi Jawa Tengah, sumber pendapatan daerah asal, dan sumber devisa bagi Indonesia, sehingga pada akhirnya akan meningkatkan pertumbuhan ekonomi Propinsi Jawa Tengah.
Gambar 2 menampakkan pertumbuhan ekonomi Propinsi Jawa Tengah dari tahun 2014 s.d tahun 2018 berfluktuasi secara berurutan adalah 5,27 persen, 5,47 persen, 5,25 persen, 5,26 persen, dan 5,32 persen. Fenomena yang terjadi pertumbuhan ekonomi Propinsi Jawa Tengah paling rendah dengan jumlah Pekerja Migran Indonesia (PMI) Propinsi Jawa Tengah yang tinggi setelah jumlah Pekerja Migran Indonesia (PMI) Propinsi Jawa timur Pertumbuhan ekonomi Propinsi Jawa Tengah setelah Propinsi DKI Jakarta, Propinsi DI Yogyakarta, Propinsi banten, Propinsi Jawa Barat, dan Propinsi Jawa Timur. 
Gambar 2

Pertumbuhan Ekonomi Propinsi di Pulau Jawa Tahun 2014-2018 (persen)

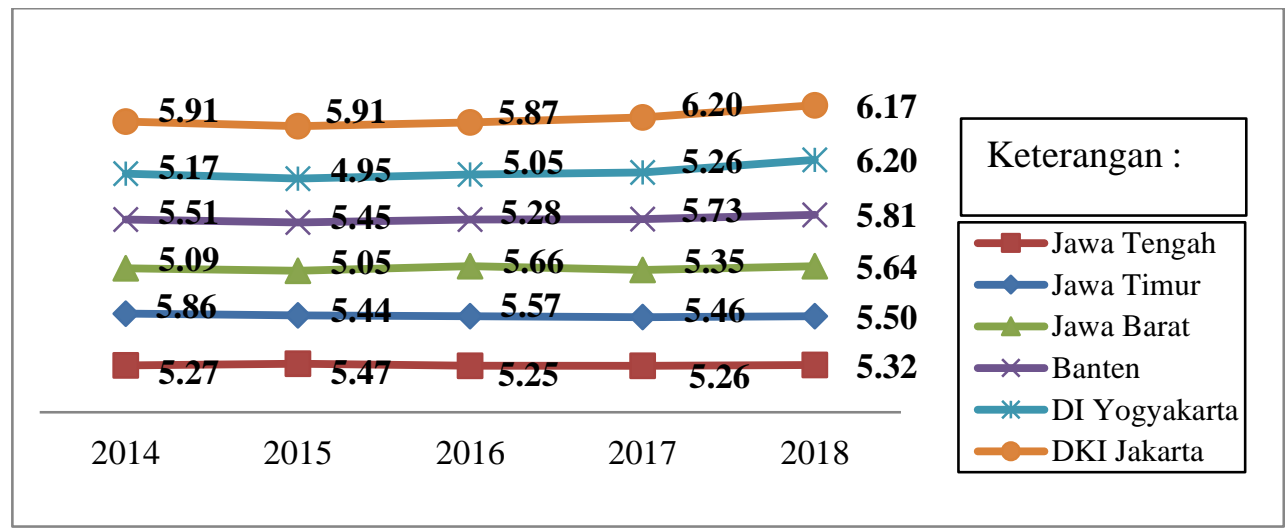

Sumber : Jawa Tengah dalam Angka 2019, diolah

Faktor pendorong Pekerja Migran meskinpun dari tahun 2014 s.d. 2018 jumlah Indonesia (PMI) Propinsi Jawa Tengah bekerja penduduk miskin Propinsi Jawa Tengah diluar negeri adalah faktor kemiskinan dari daerah asal. Faktor kemiskinan, pengangguran, dan tidak adanya penghasilan untuk memenuhi kebutuhan sehari-hari mendorong pekerja berniat mencari penghasilan yang layak, dan mencapai kesejahteraan dengan bekerja sebagai Pekerja Migran Indonesia (PMI). Gambar 3 menampakkan bahwa jumlah penduduk miskin Propinsi Jawa Tengah banyak setelah jumlah menurun secara terus menerus, yaitu pada tahun 2014 jumlah penduduk miskin Propinsi Jawa Tengah 4.836,46 ribu jiwa, tahun 2015 jumlah penduduk miskin Propinsi Jawa Tengah ada 4.577,04 ribu jiwa, tahun 2016 jumlah penduduk miskin Propinsi Jawa Tengah ada 4.506,89 ribu jiwa, tahun 2017 jumlah penduduk miskin Propinsi Jawa Tengah ada 4.450,72 ribu jiwa, - tahun 2018 jumlah penduduk miskin penduduk miskin Propinsi Jawa Timur, Propinsi Jawa Tengah ada 3.897,20 ribu jiwa.

Gambar 3

Jumlah Penduduk Miskin Propinsi di Pulau Jawa Tahun 2014-2018 (Ribu Jiwa)

\begin{tabular}{|c|c|c|c|c|c|c|}
\hline \multirow{6}{*}{$\begin{array}{r}25,000.00 \\
20,000.00 \\
15,000.00 \\
10,000.00 \\
5,000.00\end{array}$} & & & & & & \\
\hline & & & & & & \\
\hline & & & & & & \\
\hline & & & & & & \\
\hline & & & & El & $\underline{\overline{=}}$ & \\
\hline & Jawa Tengah & Jawa Timur & Jawa Barat & Banten & DI Yogyakarta & DKI Jakarta \\
\hline$\approx 2018$ & $3,897.20$ & $4,332.59$ & $3,615.79$ & 661.36 & 460.10 & 373.12 \\
\hline$\square 2017$ & $4,450.72$ & $4,617.01$ & $4,168.44$ & 675.04 & 488.53 & 389.69 \\
\hline —2016 & $4,506.89$ & $4,703.30$ & $4,224.32$ & 658.11 & 494.94 & 384.20 \\
\hline$\square 2015$ & $4,577.04$ & $4,789.12$ & $4,435.70$ & 702.40 & 550.22 & 398.92 \\
\hline =2014 & $4,836.46$ & $4,766.79$ & $4,327.07$ & 622.83 & 544.87 & 393.98 \\
\hline
\end{tabular}

Sumber : Jawa Tengah dalam Angka 2019, diolah

Penelitian ini sangat penting untuk dilakukan karena belum ada yang melakukan penelitian ini. Tujuan penelitian ini adalah untuk menganalisis dampak spillover Pekerja Migran Indonesia (PMI) asal Propinsi Jawa Tengah terhadap Pertumbuhan Ekonomi Jawa Tengah..

\section{TINJAUAN PUSTAKA}

Hasil penelitian dari McConnell et al., (2015) diketahui bahwa ada enam (6) determinan yang mempengaruhi migrasi tenaga kerja yaitu : tenaga kerja usia diatas 18 tahun setelah lulus sekolah mencari pekerjaan dengan kriteria permintaan tenaga kerja yang sesuai; tenaga kerja dengan pendidikan tinggi dengan pengalaman tertentu akan bermigrasi ke wilayah lain untuk 193 
mencari pekerjaan, dan setelah pekerja menikah maka akan menetap bekerja dan tinggal dimana keluarga kecilnya berada; tenaga kerja mempertimbangkan jarak dan biaya transportasi untuk melakukan migrasi; tingginya tingkat pengangguran menjadi alasan mengapa tenaga kerja melakukan migrasi, dan kebijakan pemerintah terkait dengan adanya migrasi internasional akan mendorong pekerja migrasi keluar.

Kebaharuan dari penelitian ini adalah penelitian ini mengadopsi model pertumbuhan ekonomi dari Mankiw et al., (1992) yang mengembangkan model pertumbuhan ekonomi dari Solow (1956) dengan mempertimbangkan peranan pendidikan sebagai modal manusia (human capital) dalam pertumbuhan ekonomi. Penelitian ini mengasimililasi migrasi tenaga kerja internasional dari Borjas (2010) ke dalam model pertumbuhan ekonomi dari Mankiw et al., (1992) dengan menggunakan pendekatan matriks bobot spasial Euclidean Distance untuk menghitung Spatial Autoregressive Model (SAR), Spatial Error Model (SAR), dan Spatial Durbin Model (SDM). Penelitian ini mengadopsi Spatial Autoregressive Model (SAR) dari Agha dan Vedrine (2010), Spatial Error Model (SAR) dari Bruno dan Hirte
(2009) serta Spatial Durbin Model (SDM) dari Fisher et al. (2009).

\section{METODE PENELITIAN}

Penelitian ini dilakukan dengan rentang waktu 2008- sampai dengan 2019 atau 12 tahun. Sampel penelitian ini meliputi meliputi 29 kabupaten (Kabupaten Cilacap, Kabupaten Banyumas, Kabupaten Purbalingga, Kabupaten Banjarnegara, Kabupaten Kebumen, Kabupaten Purworejo, Kabupaten Wonosobo, Kabupaten Magelang, Kabupaten Boyolali, Kabupaten Klaten, Kabupaten Sukoharjo, Kabupaten Wonogiri, Kabupaten Karanganyar, Kabupaten Sragen, Kabupaten Grobogan, Kabupaten Blora, Kabupaten Rembang, Kabupaten Pati, Kabupaten Kudus, Kabupaten Jepara, Kabupaten Demak, Kabupaten Semarang, Kabupaten Temanggung, Kabupaten Kendal, Kabupaten Batang, Kabupaten Pekalongan, Kabupaten Pemalang, Kabupaten Tegal, Kabupaten Brebes), dan 6 kota (Kota Magelang, Kota Surakarta, Kota Salatiga, Kota Semarang, Kota Pekalongan, dan Kota Tegal) di Propinsi Jawa Tengah. Variabel yang digunakan dalam penelitian ini adalah :

Tabel 1

Deskripsi Variabel

\begin{tabular}{|c|c|c|c|c|}
\hline No. & Variabel & Indikator & Satuan & Sumber \\
\hline 1. & $\begin{array}{l}\text { Pertumbuhan } \\
\text { Ekonomi } \\
\text { Kabupaten/Kota }\end{array}$ & PDRB & $\begin{array}{l}\text { Jutaan } \\
\text { rupiah }\end{array}$ & BPS Jawa Tengah \\
\hline 2. & Stok Modal & $\begin{array}{l}\text { Pembentukan Modal } \\
\text { Tetap Domestik }\end{array}$ & $\begin{array}{l}\text { Jutaan } \\
\text { Rupiah }\end{array}$ & BPS Jawa Tengah \\
\hline \multirow[t]{2}{*}{3.} & $\begin{array}{lr}\text { Modal } & \text { Manusia } \\
\text { (Human } & \text { capital } \\
\text { spillover) } & \end{array}$ & & & BPS Jawa Tengah \\
\hline & $\begin{array}{l}\text { Rata-rata lama sekolah } \\
\text { (RLS) }\end{array}$ & $\begin{array}{l}\text { Rata-rata lama } \\
\text { sekolah }\end{array}$ & Tahun & BPS Jawa Tengah \\
\hline 4 & Tenaga kerja & $\begin{array}{l}\text { Penduduk berusia } 15 \\
\text { tahun ke atas yang } \\
\text { bekerja selama } \\
\text { seminggu yang lalu } \\
\text { menurut pendidikan } \\
\text { tertinggi yang } \\
\text { ditamatkan } \\
\text { (tidak/belum sekolah } \\
\text { universitas) di negara }\end{array}$ & Pekerja & BPS Jawa Tengah \\
\hline 5 & $\begin{array}{l}\text { Pekerja Migran } \\
\text { Indonesia }\end{array}$ & $\begin{array}{lr}\text { Setiap warga } & \text { negara } \\
\text { Indonesia } & \text { yang } \\
\end{array}$ & Pekerja & BP2TKI \\
\hline
\end{tabular}




\begin{tabular}{|c|c|c|c|c|}
\hline No. & Variabel & Indikator & Satuan & Sumber \\
\hline & & akan,sedang & & \\
\hline & & telah melakukan & & \\
\hline & & pekerjaan dengan & & \\
\hline & & menerima & & \\
\hline & & wilayah & & \\
\hline & & Indonesia & & \\
\hline
\end{tabular}

Metode penelitian ini menggunakan matriks bobot spasial dengan Euclidean Distance dengan cara memasukkan peta Jawa Tengah ke dalam Program GeoDa 1.14 yang launching Agustus 2019 untuk mengetahui titik koordinat $\mathrm{x}$ dan titik koordinat y dari 29 Kabupaten dan 6 Kota di Propinsi Jawa Tengah. Matriks bobot spasial dengan Euclidean Distance digunakan untuk menghitung Spatial Autoregressive Model (SAR), Spatial Error Model (SAR), dan Spatial Durbin Model (SDM). Tabel 2 menunjukkan matriks bobot spasial dengan Euclidean Distance dari 29 kabupaten dan 6 kota di Propinsi Jawa Tengah. Alasan penggunaan matriks bobot spasial dengan Euclidean Distance dalam penelitian ini adalah untuk mengatasi permasalahan perhitungan dari adanya keterbatasan dari perhitungan jarak. Contoh jarak tempuh dari Semarang ke Jakarta 456,02 $\mathrm{km}$, jarak tempuh dari Semarang ke Banjarrnegara 156,5 km. Perjalanan dari Semarang ke Jakarta lebih jauh dari jarak Semarang ke Banjarnegara, namun dengan menggunakan moda pesawat terbang jarak tempuh Semarang-Jakarta lebih singkat daripada perjalanan dari Semarang ke Banjarnegara dengan menggunakan moda travel atau angkutan darat.

Tabel 2

Matrik Bobot Spasila dengan Euclidean Distance

\begin{tabular}{lcc}
\hline \multicolumn{1}{c}{ Kabupaten/Kota } & Titik Koordinat X & Titik Koordinat Y \\
\hline Kabupaten Cilacap & 108,89 & $-7,49$ \\
Kabupaten Demak & 110,63 & $-6,91$ \\
Kabupaten Grobogan & 110,93 & $-7,12$ \\
Kabupaten Banjarnegara & 109,66 & $-7,35$ \\
Kabupaten Banyumas & 109,18 & $-7,46$ \\
Kabupaten Batang & 109,86 & $-7,02$ \\
Kabupaten Blora & 111,39 & $-7,07$ \\
Kabupaten Boyolali & 110,65 & $-7,42$ \\
Kabupaten Brebes & 108,93 & $-7,06$ \\
Kota Magelang & 110,22 & $-7,48$ \\
Kabupaten Jepara & 110,77 & $-6,55$ \\
Kabupaten Karanganyar & 111,02 & $-7,66$ \\
Kabupaten Kebumen & 109,62 & $-7,65$ \\
Kabupaten Kendal & 110,16 & $-7,04$ \\
Kabupaten Klaten & 110,62 & $-7,69$ \\
Kabupaten Magelang & 110,25 & $-7,50$ \\
Kabupaten Pati & 111,04 & $-6,74$ \\
Kota Salatiga & 110,50 & $-7,74$ \\
Kota Pekalongan & 109,68 & $-6,89$ \\
Kota Semarang & 110,39 & $-7,02$ \\
Kota Surakarta & 110,82 & $-7,56$ \\
Kota Tegal & 109,12 & $-6,87$ \\
Kabupaten Kudus & 109,62 & $-7,06$ \\
Kabupaten Pekalongan & 109,40 & $-7,04$ \\
& &
\end{tabular}




\begin{tabular}{lcr}
\hline \multicolumn{1}{c}{ Kabupaten/Kota } & Titik Koordinat X & Titik Koordinat Y \\
\hline Kabupaten Pemalang & 109,40 & $-7,04$ \\
Kabupaten Tegal & 109,16 & $-7,03$ \\
Kabupaten Temanggung & 110,14 & $-7,06$ \\
Kabupaten Wonogiri & 110,99 & $-7,26$ \\
Kabupaten Wonosobo & 109,91 & $-7,42$ \\
Kabupaten Purbalingga & 109,41 & $-7,32$ \\
Kab. Purworejo & 109,97 & $-7,71$ \\
Kabupaten Rembang & 111,46 & $-6,78$ \\
Kabupaten Semarang & 110,47 & $-7,27$ \\
Kabupaten Sragen & 110,97 & $-7,39$ \\
Kabupaten Sukoharjo & 110,83 & $-7,68$ \\
\hline Suber : data
\end{tabular}

Sumber : data diolah, 2019 (Caroline, 2019)

Metode penelitian ini menggunakan ekonometrika spasial dalam bentuk Spatial Autoregressive Model (SAR), Spatial Error Model (SAR), dan Spatial Durbin Model (SDM).

Model terbaik dalam penelitian ini adalah spatial autoregressive panel model fixed effect ditulis :

$$
\begin{aligned}
& P D R B_{i t}=\rho \sum_{j=1}^{n} W_{i j} P D R B_{j t}+ \\
& \beta X_{\text {KAPITAL } i t-1}+ \\
& \beta X_{R L S_{i t-1}}+\beta X_{i t-1 \text { Tenagakerja }}+ \\
& \beta X_{i t-1 \text { Pekerja Migran Indonesia }}+\varepsilon_{i} \\
& \text { Keterangan : } \\
& i=1, \ldots, \mathrm{n} \\
& i \neq j \\
& i=\text { Kabupaten } / \text { kota yang } \\
& \text { diobservasi } \\
& \mathrm{j}=\text { Kabupaten/kota tetangga } \\
& \rho \quad=i \neq j \\
& \mathrm{~W}=\text { Matrik bobot spasial dengan } \\
& \text { pendekatan Euclidean } \\
& \text { Distance } \\
& \beta=\text { Koefisien regresi } \\
& \text { RLS = Rata-rata lama sekolah } \\
& \text { PMI = Pekerja Migran Indonesia } \\
& \varepsilon_{i} \quad=\text { errorterm }
\end{aligned}
$$

Model yang digunakan lainnya dalam penelitian adalah SEM Fixed Effec . SEM digunakan untuk mentolerir variabel yang tidak termasuk dalam model. SEM dalam penelitian ini ditulis,

$$
\begin{gathered}
P D R B_{i}=\beta_{\text {constanta }}+\beta X_{i K A P}+ \\
\beta X_{i R L S}+\beta X_{\text {iTenagakerja }}+
\end{gathered}
$$

$\beta X_{\text {iTPekerja Migran Indonesia }}+$ $\varepsilon_{i} \sum_{i=1, i \neq j}^{n} W_{i j} P D R B_{i}$

Keterangan :

$i \quad$ Kabupaten/kota yang diobservasi

$j \quad$ Kabupaten/kota tetangga

$\rho \quad$ Koefisien autoregresi ruang

W Matrik bobot spasial pendekatan Euclidean Distance

$\beta \quad$ Koefisien regresi

Rata-rata lama sekolah

Pekerja Migran Indonesia

$\varepsilon_{i} \quad$ errorterm

$\varepsilon \quad \lambda W \varepsilon+\mu$

$\lambda$ merupakan koefisien autoregresi ruang

Penelitian ini mengadopsi Spatial Durbin Model (SDM) dari Fisher et al. (2009) untuk menganalisis human capital spillover dengan model ditulis,

$$
\begin{aligned}
& P D R B_{t}=\rho \sum_{j=1}^{n} W_{i j} P D R B_{j t}+\gamma_{y} \ln Y_{i, t-1}+ \\
& \beta_{\text {Kap }} \ln \text { Kap }_{i t}+\beta_{R L S} L n_{-} R L S_{i t}+ \\
& \beta_{\text {Tenaga Kerja }} L n_{\text {Tenaga }} \text { kerja }_{i t}+ \\
& \beta_{P M I} L n_{T} P M I_{i t}+\beta_{x} X_{i t}+ \\
& \theta_{R L S} \sum_{j=1}^{N} w_{i j} \ln { }_{-} R L S_{j, t-1}+\theta_{x} \sum_{j=1}^{N} w_{i j} X_{j t}+ \\
& \alpha_{t}+\mu_{i}+\varepsilon_{i t} \\
& \text { Keterangan: }
\end{aligned}
$$

$i \quad=$ Kabupaten/kota yang diobservasi
$j \quad=$ Kabupaten/kota tetangga
PMI $=$ Pekerja Migran Indonesia
$w$ adalah matrik bobot spasial dengan
pendekatan Euclidean Distance
$\alpha_{t}$ adalah dampak spesifik waktu
$\mu_{i}$ dampak spesifik Kabupaten/kota
$\varepsilon_{\text {it }}$ adalah eror pada Kabupaten/kota i dan
waktu t
$\beta_{x}$ adalah dampak langsung dari human capital


$\rho$ adalah nilai estimasi dampak dari limpahan pertumbuhan ekonomi Kabupaten/kota tetangga

$\theta_{\mathrm{X}}$ merupakan efek tidak langsung (spillover) variabel kontrol

$\theta_{\mathrm{RLS}}$, dan $\theta_{\mathrm{X}}$ merupakan efek tidak langsung (spillover) dari human capital dalam bentuk RLS (rata-rata lama sekolah).

\section{HASIL DAN PEMBAHASAN}

Sebelum memverifikasi model regresi spasial data panel terlebih dahulu dilakukan uji regresi klasik yaitu goodness of fit, kemudian uji LM dan robust LM. Uji LM digunakan untuk mengetahui model apa yang paling cocok digunakan dalam model, apakah model spasial lag atau model spasial error (Anselin, 2005). Selanjutnya untuk menguji fixed effect (dampak tetap) atau error effect (dampak error) digunakanlah uji Likelihood Ratio.

Tabel 3 mengidentifasikan hasil perhitungan regresi klasik OLS Pooled variabel yang memiliki pengaruhi positif dan signifikan pada PDRB adalah kostanta, Kapital, PMI. Konstanta dengan koefisien 15,39839; Kapital memiliki pengaruh positif dengan koefisien 5.31e-07 pada tingkat signifikan $\alpha=1 \%$; PMI memiliki pengaruh positif dengan koefisien 0,0002 pada tingkat signifikan $\alpha=5 \%$.

Tabel 3

Hasil Perhitungan Regresi dengan Metode OLS Pooled

\begin{tabular}{crrr}
\hline Variabel & Koefisien & t-Statistic & $\mathbf{P}>|\mathbf{t}|$ \\
\hline Konstanta & $\left.15,39839^{*}\right)$ & 19,09 & 0,000 \\
Kapital & $\left.5.31 \mathrm{e}-07^{*}\right)$ & 0,12 & 0,901 \\
RLS & 0,0046438 & 0,12 & 0,901 \\
TENAGA & $1.67 \mathrm{e}-07$ & 0,71 & 0,477 \\
KERJA & & & \\
PMI & $\left.0,0002^{* *}\right)$ & 2,25 & 0,025 \\
\hline Jumlah & & & 420 \\
observasi & & & \\
$R$ squared & & & 0,4863 \\
\hline
\end{tabular}

Sumber : data diolah

Keterangan :

Variabel terikat : PDB per kapita

*signifikan pada level 1 persen;

** signifikan pada level 5 persen
SAR fixed effect digunakan untuk menganalisis yang ada tidaknya korelasi spasial antar variabel independen. SAR fixed effect disebut juga dengan Spatial Lag Model (SLM). Data panel spasial memperhatikan interaksi spasial antar kabupaten/kota di Propinsi Jawa Tengah. Adapun spatial lag yang dimaksud adalah spatial lag dalam hal pertumbuhan ekonomi kabupaten/kota di Propinsi Jawa Tengah yang saling terkait antar satu sama lain secara kedekatan geografis. Misalnya, ketika kabupaten/kota di sekitar Propinsi Jawa Tengah tumbuh sebesar $\mathrm{X} \%$, maka hal tersebut mempunyai dampak ke pertumbuhan Propinsi Jawa Tengah sebesar Y\%.

Tabel 4

Estimasi Parameter SAR Fixed Effect

\begin{tabular}{lrr}
\hline & \multicolumn{2}{c}{ SAR Fixed Effect } \\
Variabel Independen & \multicolumn{1}{c}{ Koefisien } & Zhitung \\
\hline KAP & $\left.3.05 \mathrm{e}-07^{\star}\right)$ & 15,28 \\
RLS & $-0,0261327$ & $-0,78$ \\
TENAGA KERJA & $-1,01 \mathrm{e}-07$ & $-0,30$ \\
PMI & $-1.87 \mathrm{e}-06$ & $-0,31$ \\
\hline Spatial rho & $\left.0,7835067^{*}\right)$ & 27,51 \\
\hline
\end{tabular}

Keterangan :

Variabel dependen PDRB

*) = tingkat signifikan pada $\alpha=1 \%$

$\left.{ }^{* *}\right)=$ tingkat signifikan pada $\alpha=5 \%$

Level of confidence yang digunakan dalam penelitian ini adalah $\alpha=5 \%$

$i=29$ kabupaten (Kabupaten Cilacap, Kabupaten Banyumas, Kabupaten Purbalingga, Kabupaten Banjarnegara, Kabupaten Kebumen, Kabupaten Purworejo, Kabupaten Wonosobo, Kabupaten Magelang, Kabupaten Boyolali, Kabupaten Klaten, Kabupaten Sukoharjo, Kabupaten Wonogiri, Kabupaten Karanganyar, Kabupaten Sragen, Kabupaten Grobogan, Kabupaten Blora, Kabupaten Rembang, Kabupaten Pati, Kabupaten Kudus, Kabupaten Jepara, Kabupaten Demak, Kabupaten Semarang, Kabupaten Temanggung, Kabupaten Kendal, Kabupaten Batang, Kabupaten Pekalongan, Kabupaten Pemalang, Kabupaten Tegal, Kabupaten Brebes), dan 6 kota (Kota Magelang, Kota Surakarta, Kota Salatiga, Kota Semarang, Kota Pekalongan, dan Kota Tegal) di Propinsi Jawa Tengah.

$t=2008,2009,2010,2011,2012,2013$, 2014, 2014, 2015, 2016, 2017, 2018 dan 2019

$\mathrm{P}=\mathrm{PMI}=$ Pekerja Migran Indonesia

$\mu_{i}=$ efek spesifik spasial 
$\varepsilon_{i t}=$ error yang berdistribusi independen dan identik untuk setiap $i$ dan $t$ dengan mean 0 dan varians $\sigma^{2}$.

Spatial autoregressive dengan fixed effect menunjukkan bahwa hasil yang signifikan untuk variabel kapital, dan variabel spasial lag. Variabel spasial lag menunjukkan bahwa terjadi spillover pertumbuhan ekonomi kabupaten/kota di Propinsi Jawa Tengah sebesar $0,7 \%$. Jika rata-rata kabupaten/kota tetangga tumbuh sekitar 1\%, maka akan hal tersebut akan mendorong pertumbuhan Propinsi Jawa Tengah 0,7\%. Hal ini dibuktikan oleh :

Koefisien spasial lag $(\sigma)=0,7835067$ dengan tingkat signifikansi $\alpha=1 \%$ menunjukkan bahwa besarnya interaksi nilai pertumbuhan ekonomi suatu kabupaten/kota terhadap pertumbuhan ekonomi suatu kabupaten/kota tetangganya adalah $0,7 \%$.

Koefisien kapital sebesar 3.05e-07 menunjukkan bahwa kenaikan 1\% kapital akan menaikkan pertumbuhan ekonomi sebesar 3.05e-07. ditulis :

Persamaan SAR dengan fixed-effect

$$
\begin{gathered}
P R D B_{i t}=0,7835067 \sum_{j=1}^{N} w_{i j} P R B_{j t}+ \\
3.05 \mathrm{e}-07 K A P I T A L_{i t}-0,0261327 R L S_{i t}- \\
1,01 \mathrm{e}-0710 T E N A G A K E R J A_{i t}+-1.87 \mathrm{e}- \\
06 P M I_{i t}+\mu_{i}+\varepsilon_{i t}
\end{gathered}
$$

Spasial rho 7 persen artinya jika Propinsi Jawa Tengah tumbuh 7 persen maka akan mempengaruhi 29 kabupaten (Kabupaten Cilacap, Kabupaten Banyumas, Kabupaten Purbalingga, Kabupaten Banjarnegara, Kabupaten Kebumen, Kabupaten Purworejo, Kabupaten Wonosobo, Kabupaten Magelang, Kabupaten Boyolali, Kabupaten Klaten, Kabupaten Sukoharjo, Kabupaten Wonogiri, Kabupaten Karanganyar, Kabupaten Sragen, Kabupaten Grobogan, Kabupaten Blora, Kabupaten Rembang, Kabupaten Pati, Kabupaten Kudus, Kabupaten Jepara, Kabupaten Demak, Kabupaten Semarang, Kabupaten Temanggung, Kabupaten Kendal, Kabupaten Batang, Kabupaten Pekalongan, Kabupaten Pemalang, Kabupaten Tegal, Kabupaten Brebes), dan 6 kota (Kota Magelang, Kota Surakarta, Kota Salatiga, Kota Semarang, Kota Pekalongan, dan Kota Tegal) di Propinsi Jawa Tengah dengan korelasi produktivitasnya sebesar 3,5 persen.

Catatan :

$7 \times 0,5$ persen $=3,5$ persen
Asumsinya : ceteris paribus secara rata-rata berpengaruh.

SEM fixed effect dalam penelitian ini digunakan untuk menganalisis ada tidaknya korelasi spasial antar error dalam model. Tabel 4. mengidentifikasikan hasil estimasi parameter Spatial Error Model (SEM) dengan dampak tetap dengan metode Maximum Likelihood Estimator (MLE). Berdasarkan output hasil olah Stata versi 14, hasil dari SEM fixed effect menunjukkan adanya dependensia spasial pada error. Hal ini tampak dari Kapital, AHH memiliki tanda positif dan signifikan kurang dari $\alpha=5 \%$. Level of confidence dalam penelitian ini menggunakan $\alpha=5 \%$. Koefisien Kapital 2,9e-07 dengan tingkat signifikan $\alpha=1 \%$.

\section{SIMPULAN}

Spillover tenaga kerja Propinsi Jawa Tengah yang diwujudkan dalam bentuk pekerja Migran Indonesia asal Jawa Tengah kebanyakan berasal dari Kabupaten Cilacap, Kabupaten Kendal, Kabupaten Brebes, Kabupaten Banyumas, Kabupaten Pati, Kabupaten Grobogan, Kabupaten Kebumen, Kabupaten Wonosobo, dan Kabupaten Batang dengan tingkat pendidikan Sekolah Menengah Pertama (SMP) dengan jenis kelamin wanita kebanyakan bekerja pada negara Negara Hongkong, Negara Taiwan, Negara Malaysia, Negara Singapura, Negara Korea Selatan, Negara Brunai Darussalam, dan Negara Saudi Arabia.

Pemerintah Indonesia lebih menyeleleksi Pekerja Migran Indonesia (PMI) Propinsi Jawa Tengah dengan mendaftar lebih rinci kondisi keberadaan Pekerja Migran Indonesia (PMI) Propinsi Jawa Tengah dengan memuat kartu elektronik untuk Pekerja Migran Indonesia (PMI) Propinsi Jawa Tengah sehingga kondisi, keberadaan, kesehatan, keselamatan Pekerja Migran Indonesia (PMI) Propinsi Jawa Tengah dapat dipantau, dan dapat tercatat secara akurat. Ada badan khusus yang menangani Pekerja Migran Indonesia (PMI) Propinsi Jawa Tengah dengan memuat kartu elektronik untuk Pekerja Migran Indonesia (PMI) Propinsi Jawa Tengah yang mengalami perlakuan tidak manusiawi seperti tidak digaji, disiksa, bahkan dibunuh majikan atau membunuh majikan. 
Tabel 4

Estimasi Parameter SEM Fixed Effect

\begin{tabular}{lrr}
\hline & \multicolumn{2}{c}{ SEM Fixed Effect } \\
Variabel Independen & Koefisien & Zhitung \\
\hline KAP & $\left.2,9 \mathrm{e}-07^{\star}\right)$ & 14,57 \\
RLS & $-0,0308938$ & $-0,93$ \\
TENAGA KERJA & $-2,4 \mathrm{e}-07$ & $-0,73$ \\
PMI & $-3,08 \mathrm{e}-06$ & $-0,49$ \\
\hline Spatial Lambda & $\left.0,8796821^{*}\right)$ & 35,33 \\
\hline
\end{tabular}

Keterangan :

Variabel dependen PDRB

${ }^{*}$ ) tingkat signifikan pada $\alpha=1 \%$

$\left.{ }^{* *}\right)=$ tingkat signifikan pada $\alpha=5 \%$

Level of confidence yang digunakan dalam penelitian ini adalah $\alpha=5 \%$

$i=29$ kabupaten (Kabupaten Cilacap, Kabupaten Banyumas, Kabupaten Purbalingga, Kabupaten Banjarnegara, Kabupaten Kebumen, Kabupaten Purworejo, Kabupaten Wonosobo, Kabupaten Magelang, Kabupaten Boyolali, Kabupaten Klaten, Kabupaten Sukoharjo, Kabupaten Wonogiri, Kabupaten Karanganyar, Kabupaten Sragen, Kabupaten Grobogan, Kabupaten Blora, Kabupaten Rembang, Kabupaten Pati, Kabupaten Kudus, Kabupaten Jepara, Kabupaten Demak, Kabupaten Semarang, Kabupaten Temanggung, Kabupaten Kendal, Kabupaten Batang, Kabupaten Pekalongan, Kabupaten Pemalang, Kabupaten Tegal, Kabupaten Brebes), dan 6 kota (Kota Magelang, Kota Surakarta, Kota Salatiga, Kota Semarang, Kota Pekalongan, dan Kota Tegal) di Propinsi Jawa Tengah.

$t=2008,2009,2010,2011,2012,2013,2014,2014$ 2015, 2016, 2017, 2018 dan 2019

PMI = Pekerja Migran Indonesia

$\varepsilon_{i}=$ errorterm

$\varepsilon \quad=\lambda W \varepsilon+\mu$

$\lambda=$ merupakan koefisien autoregresi ruang

Spatial Error Model dengan Fixed Effect menujukkan adanya dependensia spasial pada error. Hal ini tampak dari Kapital memiliki tanda positif dan signifikan kurang dari $\alpha=$ $5 \%$. Level of confidence penelitian ini menggunakan $\alpha=5 \%$. Koefisien kapital 2,9e07dengan tingkat signifikan $\alpha=1 \%$. Peran Lambda sangat penting bagi Spatial Error Model dengan Fixed Effect. Hal ini dibuktikan dengan Lambdha yang positif dan signifikan pada $\alpha=1 \%$.Artinya ada keterkaitan pertumbuhan ekonomi antara 29 kabupaten dan 9 kota di Propinsi Jawa Tengah. Artinya pertumbuhan ekonomi Propinsi Jawa Tengah dipengaruhi oleh kapital, RLS, dan Tenaga
Kerja. Serta residual spasial dari 29 kabupaten (Kabupaten Cilacap, Kabupaten Banyumas, Kabupaten Purbalingga, Kabupaten Banjarnegara, Kabupaten Kebumen, Kabupaten Purworejo, Kabupaten Wonosobo, Kabupaten Magelang, Kabupaten Boyolali, Kabupaten Klaten, Kabupaten Sukoharjo, Kabupaten Wonogiri, Kabupaten Karanganyar, Kabupaten Sragen, Kabupaten Grbogan, Kabupaten Blora, Kabupaten Rembang, Kabupaten Pati, Kabupaten Kudus, Kabupaten Jepara, Kabupaten Demak, Kabupaten Semarang, Kabupaten Temanggung, Kabupaten Kendal, Kabupaten Batang, Kabupaten Pekalongan, Kabupaten Pemalang, Kabupaten Tegal dan Kabupaten Brebes) dan 6 Kota (Kota Magelang, Kota Surakarta, Kota Salatiga, Kota Semarang, Kota Pekalongan, Kota Tegal) yang berada di Propinsi Jawa Tengah dan memiliki karasteristik yang sama.

Peranan Lambda sangat penting dalam Koefisien Lambda SEM fixed effect. Hal ini dibuktikan dengan Lambda bertanda positif dan signifikan pada $1 \%$, artinya ada keterkaitan pertumbuhan ekonomi antar Kabupaten/Kota lainnya di Propinsi Jawa Tengah. Artinya pertumbuhan ekonomi Propinsi Jawa Tengah dipengaruhi oleh nilai Kapital dan residual spasial dari 29 kabupaten dan 6 kota lainnya yang berdekatan (Kabupaten Cilacap, Kabupaten Banyumas, Kabupaten Purbalingga, Kabupaten Banjarnegara, Kabupaten Kebumen, Kabupaten Purworejo, Kabupaten Wonosobo, Kabupaten Magelang, Kabupaten Boyolali, Kabupaten Klaten, Kabupaten Sukoharjo, Kabupaten Wonogiri, Kabupaten Karanganyar, Kabupaten Sragen, Kabupaten Grbogan, Kabupaten Blora, Kabupaten Rembang, Kabupaten Pati, Kabupaten Kudus, Kabupaten Jepara, Kabupaten Demak, Kabupaten Semarang, Kabupaten Temanggung, Kabupaten Kendal, Kabupaten Batang, Kabupaten Pekalongan, Kabupaten Pemalang, Kabupaten Tegal dan Kabupaten Brebes, Kota Magelang, Kota Surakarta, Kota Salatiga, Kota Semarang, Kota Pekalongan, Kota Tegal) dan memiliki karasteristik yang sama.

Persamaan Spatial Error Model dengan Fixed Effect adalah : 
Pertumbuhan Ekonomi $i_{i t}$

$=2,9 \mathrm{e}-07$ Kapital $_{i t}-0,0308938 R L S_{i t}-2,4 \mathrm{e}$

- 07Tenaga Kerja ${ }_{i t}-3,08 \mathrm{e}-06 P M I_{i t}$ $+0,8796821 \sum_{j=1}^{N} w_{i j}$ Pertumbuhan ekonomi $i_{j t}$

Penelitian ini menggunakan analisis spatial durbin model fixed effect karena pada spatial durbin model random effect mengandung model konvergensi ketika spatial durbin model random effect mencari nilai likelihood yang maksimum, sehingga hasil yang didapat pada spatial durbin model random effect bisa jadi kurang valid secara statistik.

Tabel 5. mengidentifikasikan bahwa variabel yang berpengaruh signifikan terhadap pertumbuhan ekonomi adalah: Kap, dan RLS dengan nilai $p$ value kurang dari 5\%. Kemudian dampak spasial human capital spillover terhadap pertumbuhan ekonomi Propinsi Jawa Tengah dijelaskan oleh model SDM FE, dimana variabel Kapital, RLS, dan Tenaga Kerja dari kabupaten/kota tetangga tidak berpengaruh terhadap pertumbuhan ekonomi domestik yang ditunjukan oleh p-value yang lebih kecil dari 0,05 artinya signifikan. Dampak spasial dari pertumbuhan ekonomi kabupaten/kota tetangga ke kabupaten/kota domestik di Propinsi Jawa Tengah tetap signifikan dengan efek sebesar setiap pertumbuhan kabupaten/kota tetangga 1 persen berkontribusi ke pertumbuhan dalam kabupaten/kota sebesar 0,28 persen.

Tabel 5

Spatial Durbin Model dengan Fixed Effect

\begin{tabular}{|c|c|c|}
\hline Variabel Independen & Koefisien & Zhit \\
\hline Spasial lag & $\left.0,2869493^{*}\right)$ & 1,98 \\
\hline \multicolumn{3}{|l|}{$\begin{array}{l}\text { Pertumbuhan Ekonomi } \\
(\rho) \text { atau Spasial rho }\end{array}$} \\
\hline KAPITAL & $\left.3,05 \mathrm{e}-07^{*}\right)$ & 15,21 \\
\hline RLS & $\left.0,069563^{\star *}\right)$ & $-1,96$ \\
\hline TENAGA KERJA & $3,17 \mathrm{e}-07$ & 0,86 \\
\hline PMI & $-3.73 e-06$ & $-0,60$ \\
\hline \multicolumn{3}{|l|}{ Matriks Bobot Spasial } \\
\hline W_KAP & $\left.3.90 \mathrm{e}-07^{\star}\right)$ & 2.32 \\
\hline W_RLS & $\left.-1,284742^{*}\right)$ & $-2,94$ \\
\hline W_ TENAGA KERJA & $\left.0,0000204^{*}\right)$ & 3,70 \\
\hline W_PMI & -0.0000143 & $-0,66$ \\
\hline
\end{tabular}

Keterangan :

Variabel Bebas PDRB
*) adalah Tingkat signifikansi pada $\alpha=1 \%$

**) adalah Tingkat signifikansi pada $\alpha=5 \%$

$\mathrm{Wx}=$ matriks bobot spasial dengan Euclidean Distance

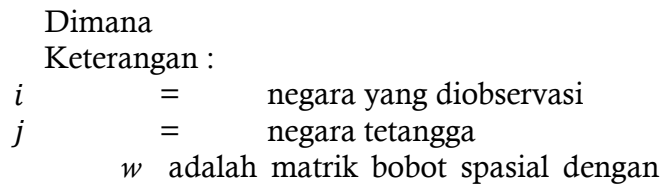

pendekatan Euclidean Distance

$\alpha_{t}$ adalah dampak spesifik waktu

$\mu_{i}$ dampak spesifik negara

$\varepsilon_{\text {it }}$ adalah eror pada negara i dan waktu $\mathrm{t}$

$\beta_{x}$ adalah dampak langsung dari human capital

$\rho$ adalah nilai estimasi dampak dari limpahan pertumbuhan ekonomi negara tetangga $\theta_{\mathrm{X}}$ merupakan efek tidak langsung (spillover) variabel kontrol

$\theta_{R L S}$, dan $\theta_{\mathrm{X}}$ merupakan efek tidak langsung (spillover) dari human capital dalam bentuk RLS

$\begin{array}{lll}\text { RLS } & = & \text { Rata-rata lama sekolah } \\ \mathrm{PMI} & = & \text { Pekerja Migran Indonesia }\end{array}$

Dampak dari spillover Pekerja Migran Indonesia asal Propinsi Jawa tengah ditunjukkan pada Spatial Durbin Model (SDM) dengan fixed effect ditampakkan melalui identifikasi nilai koefisien matrik bobot spasial W_KAPITAL sebesar 3.90e-07 dengan tingkat signifikan $\alpha=$ $1 \%$, nilai koefisien matrik bobot spasial W_RLS dengan nilai koefisien sebesar -1,284742dengan tingkat signifikan $\alpha=1 \%$, dan nilai koefisien matrik bobot spasial W_TENAGA KERJA sebesar 0,0000204 dengan tingkat signifikan $\alpha=$ $1 \%$.

Spatial durbin model fixed effect dalam penelitian ini ditulis :

$P D R B_{i t}=0,2869493 \sum_{j=1}^{n} W_{i j} P D R B_{j t}+$ $\gamma_{y} \ln Y_{i, t-1}+3,05 \mathrm{e}-07_{K a p} \ln K_{\text {Kap }}+$ $-0,069563_{R L S} L n_{-} R L S_{i t}+3,17 \mathrm{e}-$

$07_{\text {Tenaga Kerja }} L n_{\text {Tenaga }}$ kerja $a_{i t}--3.73 \mathrm{e}-$

$06_{P M I} L_{P M I}+\beta_{x} X_{i t}+3.90 \mathrm{e} \quad-\quad 3.90 \mathrm{e}-$

$07_{\text {KAPITAL }} \sum_{j=1}^{N} w_{i j} \ln \_K A P I T A L_{j, t-1}-1,284742_{R L S} \sum_{j=1}^{N} w_{i j} \ln { }_{-} R L$

$0,0000204_{\text {TENAGA KERJA }} \sum_{j=1}^{N} w 2,51 e-$

$09_{P M I} \sum_{j=1}^{N} w_{i j} \ln { }_{-} P M I_{j, t-1}+\theta_{x} \sum_{j=1}^{N} w_{i j} X_{j t}+$ $\alpha_{t}+\mu_{i}+\varepsilon_{i t}$

Interpretasi model bersdasarkan besaran koefien (magnitute) pada Spatial Durbin Model (SDM) dengan fixed effect adalah sebagai berikut

a. Peningkatan pertumbuhan ekonomi kabupaten/kota tetangga sebesar satu satuan pada tahun tertentu dengan asumsi 
variabel independen lain dianggap tetap maka akan meningkatkan pertumbuhan ekonomi domestik kabupaten/kota tersebut 0,28 persen

b. Peningkatan jumlah Kapital kabupaten/kota lain sebesar satu satuan pada tahun tertentu dengan asumsi variabel independen lain dianggap tetap maka akan meningkatkan pertumbuhan ekonomi domestik kabupaten/kota tersebut 3,05e-07 persen;

c. Peningkatan jumlah Rata-rata Lama Sekolah (RLS) sebesar satu satuan pada tahun tertentu dengan asumsi variabel independen lain dianggap tetap maka menurunkan pertumbuhan ekonomi domestik kabupaten/kota tersebut . 0,069563 persen;

d. Peningkatan jumlah Tenaga Kerja sebesar satu satuan dari kabupaten/kota tetangga pada tahun sebelumnya dengan asumsi variabel independen lainnya dianggap tetap maka dengan adanya pengaruh kedekatan wilayah dari kabupaten/kota tetangga akan menurunkan dampak negatif human capital spillover terhadap pertumbuhan ekonomi kabupaten/kota Propinsi Jawa Tengah lainnya 3, 17e-07 persen.

e. Peningkatan jumlah Pekerja Migran Indonesia sebesar satu satuan dari kabupaten/kota tetangga pada tahun sebelumnya dengan asumsi variabel independen lainnya dianggap tetap maka dengan adanya pengaruh kedekatan wilayah dari kabupaten/kota tetangga akan meningkatkan dampak positif human capital spillover terhadap pertumbuhan ekonomi kabupaten/kota Propinsi Jawa Tengah lainnya -3.73e-06 persen.

Spillover Pekerja Migran Indonesia (PMI) asal Propinsi Jawa Tengah yang bekerja diluar negeri ada 10 kabupaten. Tabel 6 menunjukkan bahwa tahun 2016 ada 9 kabupaten potensi PMI, tahun 2017 dan 2018 ada 10 kabupaten yang berpotensi PMI Jawa Tengah antara lain : Kabupaten Cilacap, Kabupaten Kendal, Kabupaten Brebes, Kabupaten Banyumas, Kabupaten Pati, Kabupaten Grobogan, Kabupaten Kebumen, Kabupaten Wonosobo, dan Kabupaten Batang.

Tabel 6

Potensi PMI asal Propinsi Jawa Tengah Tahun 2016-2018

\begin{tabular}{|c|c|c|c|c|c|c|}
\hline No & Kab/kota & 2016 & Kab/kota & 2017 & Kab/kota & 2018 \\
\hline \multirow[t]{2}{*}{1} & Kabupaten & 9.574 & Kabupaten & 10.128 & Kabupaten Cilacap & 11.785 \\
\hline & Cilacap & & Cilacap & & & \\
\hline \multirow[t]{2}{*}{2} & Kabupaten & 6.391 & Kabupaten & 7.431 & Kabupaten Kendal & 7.812 \\
\hline & Kendal & & Kendal & & & \\
\hline \multirow[t]{2}{*}{3} & Kabupaten & 4.310 & Kabupaten & 4.811 & Kabupaten Brebes & 5.995 \\
\hline & Brebes & & Brebes & & & \\
\hline \multirow[t]{2}{*}{4} & Kabupaten & 3.522 & Kabupaten & 3.764 & Kabupaten & 4.112 \\
\hline & Banyumas & & Banyumas & & Banyumas & \\
\hline \multirow[t]{2}{*}{5} & Kabupaten & 3.387 & Kabupaten Pati & 3.415 & Kabupaten Pati & 3.700 \\
\hline & Pati & & & & & \\
\hline \multirow[t]{2}{*}{6} & Kabupaten & 2.582 & Kabupaten & 2.712 & Kabupaten & 3.207 \\
\hline & Grobogan & & Grobogan & & Grobogan & \\
\hline \multirow[t]{2}{*}{7} & Kabupaten & 2.222 & Kabupaten & 2.424 & Kabupaten & 2.682 \\
\hline & Kebumen & & Kebumen & & Kebumen & \\
\hline \multirow[t]{2}{*}{8} & Kabupaten & 1.856 & Kabupaten & 2.397 & Kabupaten & 2.440 \\
\hline & Sragen & & Wonosobo & & Wonosobo & \\
\hline \multirow[t]{2}{*}{9} & Kabupaten & 1.671 & Kabupaten & 1.967 & Kabupaten Sragen & 2.257 \\
\hline & Wonosobo & & Sragen & & & \\
\hline \multirow[t]{4}{*}{10} & Kabupaten & 1.466 & Kabupaten & 1.662 & Kabupaten Batang & 1.877 \\
\hline & Batang & & Batang & & & \\
\hline & Total & 49.512 & Total & 54.737 & Total & 61.434 \\
\hline & Rata-rata & 1.456 & Rata-rata & 1.610 & Rata-rata & 1.807 \\
\hline
\end{tabular}

Sumber : BP2TKI 2019, diolah 
Pekerja Migran Indonesia (PMI) asal Tengah ada 25.606 pekerja, pada tahun 2018 Propinsi Jawa Tengah yang bekerja diluar negeri jumlah Pekerja Migran Indonesia (PMI) asal kebanyakan berjenis kelamin wanita. Jumlah Propinsi Jawa Tengah meningkat menjadi 42.630 Pekerja Migran Indonesia (PMI) asal Propinsi pekerja, dan pada tahun 2018 jumlah Pekerja Jawa Tengah dari tahun 2016 sampai dengan 2018 Migran Indonesia (PMI) asal Propinsi Jawa meningkat yaitu pada tahun 2016 jumlah Pekerja Tengah ada 46.578 pekerja.

Migran Indonesia (PMI) asal Propinsi Jawa

\section{Gambar 4}

PMI dengan Jenis Kelamin Propinsi Jawa Tengah Tahun 2016-2018

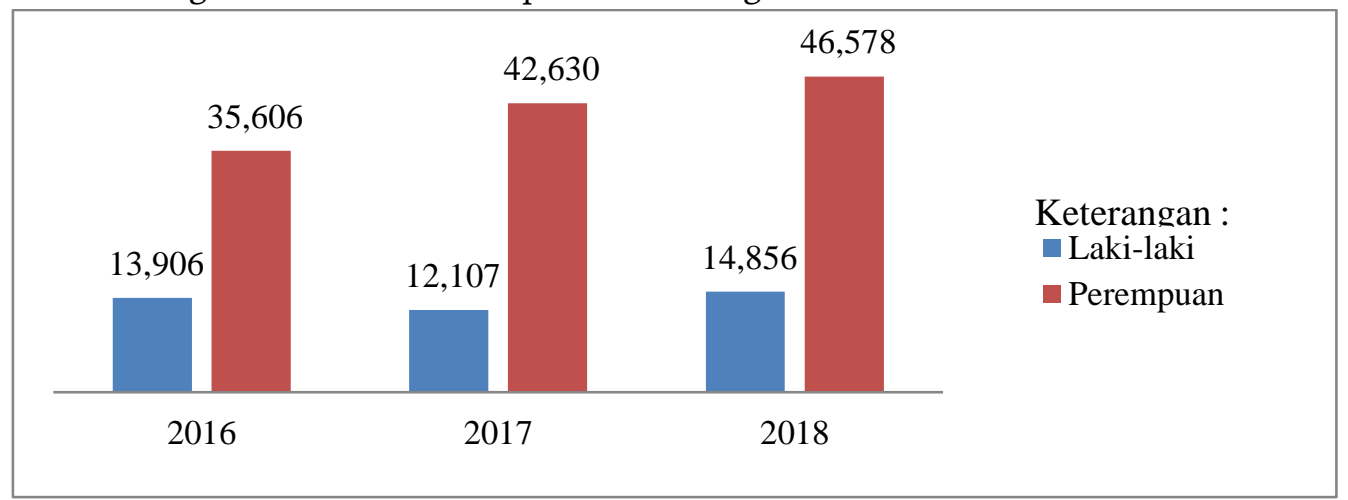

Sumber : Data BP2TKI 2019, diolah

Gambar 5 menampakkan bahwa Pekerja Pekerja Migran Indonesia (PMI) asal Propinsi Migran Indonesia (PMI) asal Propinsi Jawa Jawa Tengah tahun 2016 sampai dengan tahun Tengah yang bekerja diluar negeri tahun 20162018 adalah 28.129 pekerja, 34.912 pekerja, dan sampai dengan tahun 2018 kebanyakan bekerja 36. 502 pekerja. pada sektor informal. Secara bertutur turut jumlah

\section{Gambar 5}

PMI Jawa Tengah berdasarkan Sektor Pekerjaan Tahun 2016-2018

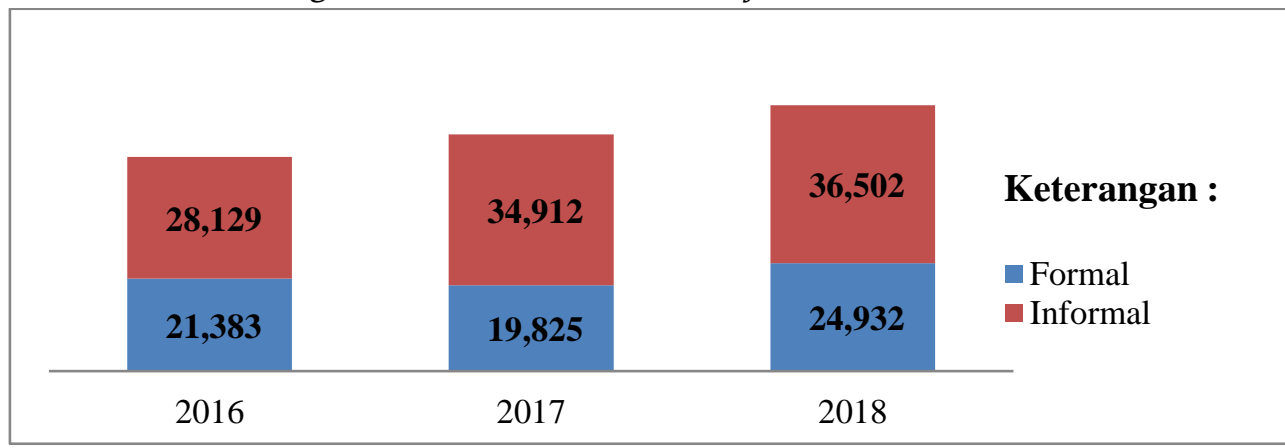

Sumber : Data BP2TKI 2019, diolah

dengan pendidikan SMP berfluktuatif yaitu pada

Gambar 6 menampakkan bahwa Pekerja Migran Indonesia (PMI) asal Propinsi Jawa Tengah yang bekerja diluar negeri tahun 2016 sampai dengan tahun 2018 kebanyakan yang bekerja dengan pendidikan tamatan SMP disusul dengan pendidikan SD, dan SMA. jumlah Pekerja Migran Indonesia (PMI) asal Propinsi Jawa Tengah tahun 2016 sampai dengan tahun 2018 tahun 2016 jumlah Pekerja Migran Indonesia (PMI) asal Propinsi Jawa Tengah ada 24.481 pekerja, tahun 2017 jumlah Pekerja Migran Indonesia (PMI) asal Propinsi Jawa Tengah ada 20.291, dan pada tahun 2018 jumlah Pekerja Migran Indonesia (PMI) asal Propinsi Jawa Tengah ada 21.101 pekerja. 


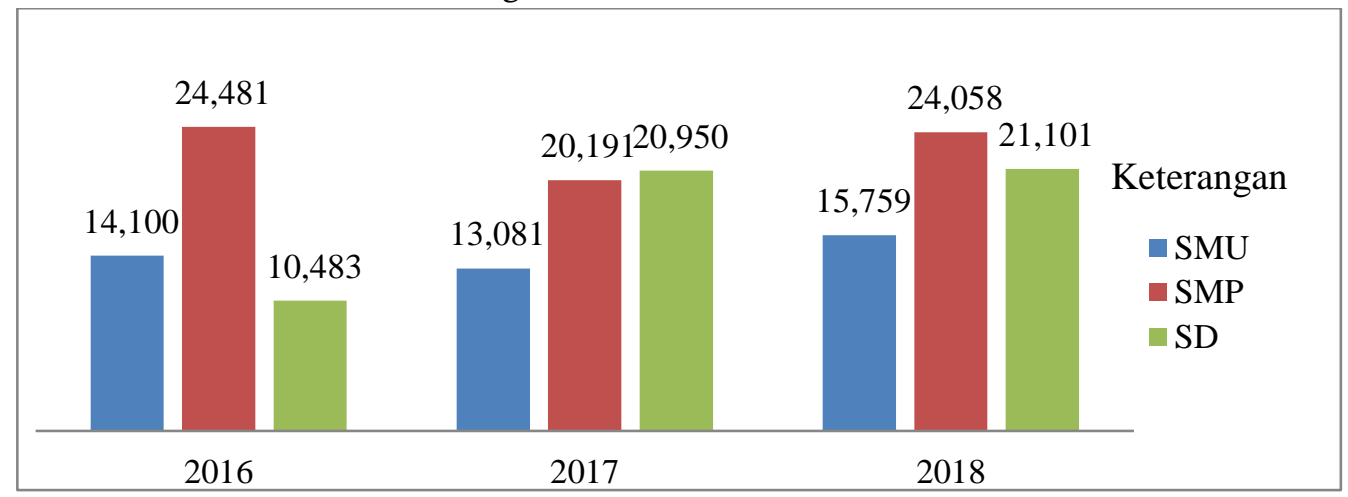

Sumber : Data BP2TKI 2019, diolah

pekerja, dan United Arab Emirates 258 pekerja.

Tabel 7 menunjukkan jumlah PMI Jawa Negara tujuan PMI Jawa Tengah tahun 2017 dan Tengah pada tahun 2018 kebanyakan bekerja pada negara Taiwan 17.761 pekerja, Malaysia 13.329 2018 kebanyakan adalah Negara Hongkong, Negara Taiwan, Negara Malaysia, Negara pekerja, Singapura 7.341 pekerja, Hongkong 4.762 Singapura, Negara Korea Selatan, Negara Brunai pekerja, Korea Selatan 2.791 pekerja, Brunei Darussalam, dan Negara Saudi Arabia. Darussalam 1.352 pekerja, Saudi Arabia 1.330

Tabel 7. Jumlah PMI Jawa Tengah Bedasarakan Negara Tujuan Tahun 2016-2018 (pekerja)

\begin{tabular}{|c|c|c|c|c|c|}
\hline Negara & 2016 & Negara & 2017 & Negara & 2018 \\
\hline Taiwan & 7.761 & Hongkong & 17.911 & Hongkong & 18.959 \\
\hline Malaysia & 13.329 & Taiwan & 15.453 & Taiwan & 17.295 \\
\hline Singapura & 7.341 & Malaysia & 12.235 & Malaysia & 12.760 \\
\hline Hongkong & 4.762 & Singapura & 4.681 & Singapura & 6.204 \\
\hline Korea Selatan & 2.791 & Korea Selatan & 1.809 & Korea Selatan & 3.629 \\
\hline Brunei & & Brunei & & Brunei & \\
\hline Darussalam & 1.352 & Darussalam & 1.049 & Darussalam & 1.014 \\
\hline Saudi Arabia & 1.330 & Saudi Arabia & 643 & Saudi Arabia & 505 \\
\hline United Arab & & & & & \\
\hline Emirates & 258 & Lainnya & 264 & Aljazair & 260 \\
\hline
\end{tabular}
Sumber : Data BP2TKI 2019, diolah

Hasil Penelitian ini didukung oleh hasil penelitian dari Skeldon (1992) dan Hugo (1993) yang menyatakan bahwa pekerja migran asal Indonesia memiliki pendidikan yang rendah dengan negara tujuan Malaysia, Arab Saudi, Hongkomg, Singapura,dan BrunaiDarussalam dengan jenis kelamin wanita, sedangkan pekerja migran berjenis kelamin pria bekerja di Korea Selatan, Taiwan dan Jepang.

\section{SIMPULAN}

Spillover tenaga kerja Propinsi Jawa Tengah yang diwujudkan dalam bentuk pekerja

Migran Indonesia asal Jawa Tengah kebanyakan berasal dari Kabupaten Cilacap, Kabupaten Kendal, Kabupaten Brebes, Kabupaten Banyumas, Kabupaten Pati, Kabupaten Grobogan, Kabupaten Kebumen, Kabupaten Wonosobo, dan Kabupaten Batang dengan tingkat pendidikan Sekolah Menengah Pertama (SMP) dengan jenis kelamin wanita kebanyakan bekerja pada negara Negara Hongkong, Negara Taiwan, Negara Malaysia, Negara Singapura, Negara Korea Selatan, Negara Brunai Darussalam, dan Negara Saudi Arabia.

Pemerintah Indonesia lebih menyeleleksi Pekerja Migran Indonesia (PMI) Propinsi Jawa 
Tengah dengan mendaftar lebih rinci kondisi keberadaan Pekerja Migran Indonesia (PMI) Propinsi Jawa Tengah dengan memuat kartu elektronik untuk Pekerja Migran Indonesia (PMI) Propinsi Jawa Tengah sehingga kondisi, keberadaan, kesehatan, keselamatan Pekerja Migran Indonesia (PMI) Propinsi Jawa Tengah dapat dipantau, dan dapat tercatat secara akurat. Ada badan khusus yang menangani Pekerja Migran Indonesia (PMI) Propinsi Jawa Tengah dengan memuat kartu elektronik untuk Pekerja Migran Indonesia (PMI) Propinsi Jawa Tengah yang mengalami perlakuan tidak manusiawi seperti tidak digaji, disiksa, bahkan dibunuh majikan atau membunuh majikan.

\section{DAFTAR PUSTAKA}

Acemoglu, D., \& Autor, D. (2011). Skills, tasks and technologies: Implications for employment and earnings. Handbook of labor economics, 4, 1043-1171.

Agha, S. B., \& Vedrine, L. (2010). Estimation strategies for a spatial dynamic panel using GMM. A new approach to the convergence issue of European regions. Spatial Economic Analysis, Vol. 5(No. 2). doi: 10.1080/17421771003730711.

Anselin, L. (1988). Model validation in spatial econometrics: a review and evaluation of alternative approaches. International Regional Science Review, 11(3), 279-316.

Anselin, L. (1995). Local indicators of spatial association-LISA. analysis, 27(2), 93-115.

Anselin, L., \& Bera, A. K. (1998). Spatial dependence in linear regression models with an introduction to spatial econometrics. Statistics Textbooks and Monographs, 155, 237-290.

Asian Development Bank. (2016). ASEAN corporate goverment scorcard : Country reports and assessment 2014, Philippines : Mandaluyong.

Bauer, T. K., \& Vorell, M. (2007). External Effects of Education : Human Capital Spillovers in Regions and Firms. Ruhr Economic Paper No. 195.

Becker, G. S. (1995). Human capital and poverty alleviation. World Bank, Human Resources Development and Operations Policy.

Benhabib, J., \& Spiegel, M. M. (1994). The Role of Human Capital in Economic Development Evidence from Aggregate
Cross-Country Data. Journal of Monetary Economics, Vol 34, pp. 143-173.

Bhargava, A., Jamison, D. T., Lau, L., \& Murray, C. J. (2001). Modeling The Effects of Health on Economic Growth. GPE Discussion Paper Series(33).

Bloom, D. C. a. J. S. (2004). "The Effect of Health on Economic Growth:A Production Function Approach." World Development Vol. 32, No. 1, pp. 1-13, 2004: 13.

Bloom, D. E., Canning, D., \& Sevilla, J. (2005). The Effect of Health on Economic Growth: A Production Function Approach. World Development, Vol. 32(1), pp. 1-13. doi: 10.1016/j.worlddev.2003.07.002.

Bloom, D. E., \& Canning, D. (2005). Health and Economic Growth : Reconciling the Micro and Macro Evidence.

Boediono, 1992. Teori Pertumbuhan Ekonomi, Yogyakarta: BPFE UGM.

Borjas, G. J. (2006). Native internal migration and the labor market impact of immigration. Journal of Human resources, 41(2), 221-258.

BP2TKI, Data Penempatan Pekerja Migran Indonesia (PMI) 2019

BP2TKI, Data Penempatan Pekerja Migran Indonesia (PMI) 2018

BP2TKI, Data Penempatan Pekerja Migran Indonesia (PMI) 2017

Brempong, K. G., \& Wilson, M. (2004). Health Human Capital and Economic Growth in Sub-Saharan African and OECD countries. The Quarterly Review of Economics and Finance, Vol. 44(2), pp. 296-320. doi: 10.1016/j.qref.2003.07.002

Brunow, S., \& Hirte, G. (2009). The Age Pattern of Human Capital and Regional Productivity: A Spatial Econometric Study an German Regions. Papers in Regional Science, Vol. 88(Issue 4), pp. 799-823. doi: 10.1111/j.1435-5957.2009.00228.x

Becker, Gary S. Human Capital a Theoretical and Empirical Analysis, with Special Reference to Education. Third Edision ed.: University Of Chicago Press 1994.

Chansarn, S. (2010). Labor Productivity Growth, Education, Health and Technological Progress: A Cross-Country Analysis. Economic Analysis and Policy, 40(2), 249-261. doi: 10.1016/s03135926(10)50027-4

Caselli, F., Esquivel, G., \& Lefort, F. (1996). Reopening the convergence debate: a new look at cross-country growth empirics. 
Journal of economic growth, 1(3), 363389.

Cliff, A. D., \& Ord, J. K. (1981). Spatial processes: models \& applications. Taylor \& Francis.

Cordner, L. G. (1994). The Spratly Islands dispute and the law of the sea. Ocean Development \& International Law, 25(1), 61-74.

Combes, P. P., Duranton, G., \& Gobillon, L. (2008). Spatial wage disparities: Sorting matters!. Journal of Urban Economics, 63(2), 723-742.

Cordesman, A. H., Hess, A., \& Yarosh, N. S. (2013). Chinese military modernization and force development. A Western Perspective. Washington: Center for Strategic \& International Studies.

Dattorro, J. (2010). Convex optimization \& Euclidean distance geometry. Lulu. com.

DaVanzo, J. (1978). Does unemployment affect migration? Evidence from micro data. The Review of Economics and Statistics, 504514.

Davies, P. S., Greenwood, M. J., \& Li, H. (2001). A conditional logit approach to US state-to-state migration. Journal of Regional Science, 41(2), 337-360.

De Mello, L. R. (1999). Foreign direct investment-led growth: evidence from time series and panel data. Oxford economic papers, 51(1), 133-151.

Dube, J., \& Legros, D. (2014). Spatial Econometrics Using Microdata: John Wiley and Sons, Inc.

Fischer, M. M., Bartkowska, M., Riedl, A., Sardadvar, S., \& Kunnert, A. (2009). The impact of human capital on regional labor productivity in Europe. Letters in Spatial and Resource Sciences, 2(2), 97-108.

Fischer, M. M., \& Wang, J. (2011). Spatial data analysis: models, methods and techniques. Springer Science \& Business Media.

Fleisher, B., Li, H., \& Zhao, M. Q. (2010). Human capital, economic growth, and regional inequality in China. Journal of development economics, 92(2), 215-231.

Fortin, M. J., \& Dale, M. R. (2009). Spatial autocorrelation. The SAGE handbook of spatial analysis, 89-103.

Fotheringham, A. S., Brunsdon, C., \& Charlton, M. (2000). Quantitative geography: perspectives on spatial data analysis. Sage.

$\mathrm{Fu}$, S. (2006). Smart Cafe Cities : Testing human capital externalities in the Boston metropolitan area. Journal of Urban Economics, Vol. 61(Issue 1), pp. 86-111. doi: 10.1016/j.jue.2006.06.002
Fuente, A. d. 1. (2006). Education and economic growth a quick review of the evidence and some policy guidelines. Prime Minister's Offfice Economic Council of Finland, Vol. 18, pp. 195-212.

Getis, A., \& Ord, J. K. (1992). The analysis of spatial association by use of distance statistics. Geographic Analysis, Vol. 24(No. 3).

Green, R. K., \& Hendershott, P. H. (2001). Home-ownership and unemployment in the US. Urban Studies, 38(9), 1509-1520.

Griffith, D., \& Chun, Y. (2014). Spatial autocorrelation and spatial filtering. In Handbook of regional science (pp. 14771507). Springer Berlin Heidelberg.

Haining, R. P. (2003). Spatial data analysis: theory and practice. Cambridge University Press.

Hugo, G. (1993). Indonesian labour migration to Malaysia: trends and policy implications. Southeast Asian Journal of Social Science, 21(1), 36-70.

Hussain, M. (2014). Export and GDP in Pakistan: Evidence from Causality and Cointegration Analysis. International Journal of Management Cases, 16, 37-46.

Islam, N. (1995). Growth Empirics Panel Data. The Quarterly Journal of Economics, Vol. 110(4), pp. 1127-1170.

Kassim, A. (1997). International Migration and Its Impact on Malaysian. Makalah disampaikan pada Confidence Building and Conflict Reduction.11th. ASPAC Rountable, Malaysia, 5-8 Juni 1997. http://www.buruhmigran.net

Knowles, S., \& Owen, P. D. (1995). Health capital and cross-country variation in income per capita in the Mankiw-RomerWeil model . Economic Letter(48), pp. 99106.

Lau, Lawrence J., Dean T. Jamison, and Frederic F. Louat. "Education and Production in Developing Countries : An Aggregat Production Function Approanch." Working Paper World Development Report (1991).

LeSage, J. P., \& Pace, R. K. (2010). Spatial econometric models. Handbook of applied spatial analysis, 355-376.

Li, Y., Chen, Z., Yan, L., \& Luo, S. (2010). Research on the Relationship between Foreign Trade and GDP Growth in West China---Empirical Analysis Based on Panel Causality. Journal of Information Processing and Management, 1(2), 84-93.

Tullao, T. S., \& Rivera, J. P. R. (2008). The impact of temporary labor migration on 
the demand for education: Implications on the human resource development in the Philippines.

Lucas, R. E. (1988). On the mechanics of economic development. Journal of monetary economics, 22(1), 3-42.

Mathur, V. K. (1999). Human Capital-Based Strategy for Regional Economic Development. Economic Development Quarterly, Vol. 13(Issue 3), pp. 203-216. doi: 10.1177/089124249901300301

Mankiw, N. G., Romer, D., \& Weil, D. N. (1992). A Contribution to The Empirics of Economic Growth. The Quarterly Journal of Economi.

Mankiw, N. G. (2009). Principles of macroeconomics. Cengage Learning.

McConnell, Brue et al. (2015). Contemporary Labor Economics. McGraw-Hill Higher Education

Mincer, J. (1978). Family migration decisions. Journal of political Economy, 86(5), 749. 773.

Moretti, E. (2004). Workers' Education, Spillovers, and Productivity Evidence from Plant-Level Production Functions. The American Economic Review, Vol. 94(Issue 3), pp. 656-690.

Nelson, R. R., \& Phelps, E. S. (1966). Investments in Humans, Technological Diffusion, and Economic Growth. American Economic Review, Vol. 56(No. 2).

Pritchett, L. (2000). Understanding Patterns of Economic Growth : Searching for Hills among Plateaus, Moutains, and Plains. The World Bank Economic Review, Vol. 14(No. 2), pp. 221-299.

Rauch, J. E. (1991). Modelling the informal sector formally. Journal of development Economics, 35(1), 33-47.

Romer, P. M. (1990). Endogenous Technogical Change. Journal of Political Economy, Vol. 98(No. 5).

Ramos, R., Surinach, J., \& Artis, M. (2010). Human capital spillovers, productivity and regional convergence in Spain. Papers in Regional Science, 89(2), 435-447.

Rosenthal, S. S., \& Strange, W. C. (2008). The attenuation of human capital spillovers. Journal of Urban Economics, 64(2), 373389.

Saaed, A. A. J., \& Hussain, M. A. (2015). Impact of exports and imports on economic growth: Evidence from Tunisia. Journal of Emerging Trends in Economics and Management Sciences, 6(1), 13.
Schultz, T. W. (1961). Investment in Human Capital. The American Economic Review, Vol. 51(1), pp. 1-17.

Shafique, S., \& Hussain, Z. (2015). The impact of foreign direct investment (FDI) on economic growth.

Sjaastad, L. A. (1962). The costs and returns of human migration. Journal of political Economy, 70(5, Part 2), 80-93.

Skeldon, R. (1997). Rural-to-urban migration and its implications for poverty alleviation. Asia-Pacific Population Journal, 12(1), 316.

Solow, R. M. (1956). A Contribution to the Theory of Economic Growth. The Quarterly Journal of Economics, Vol. 70(No. 1), pp. 65-94.

Swan, T. W. (1956). Economic growth and capital accumulation. Economic record, 32(2), 334-361.

Ullah, S., Zaman, B., Farooq, M., \& Javid, A. (2009). Cointegration and causality between exports and economic growth in Pakistan. European Journal of Social Sciences, 10(2), 264-272.

Weil, D. N. (2005). Accounting for The Effect of Health on Economic Growth. Nber Working Paper Series, Vol. 11455.

Zhen, X., \& Fen, S. (2013). Impact of Human Capital on Economic Growth Based on Spatial Economic Perspective. Information Technology Journal, Vol. 12(No. 10). Hossain, A., Anis, C. \& Elgar, P. (1998). Open-economy Macroeconomics for Developing Countries. United Kingdom.

Kucera. (2001). The effects of core workers rights on labour costs and foreign direct investment: Evaluating the "conventional wisdom". Geneva $(\mathrm{CH})$ : International Institute for Labour Studies.

Mankiw, N. G. (2007). Macroeconomics. Toronto: Thomson Nelson.

McLeod, C. \& Sophister, S. (2014). Gender Equality In The Labour market and Foreign Direct Investment. The Student Economic Review, 26, 133-141.

Melnyk, L., Oleksandr, K. \& Serhiy, P. (2014). The impact of foreign direct investment on economic growth: case of post communism transition economies. Problems and Perspectives in Management, 12(1).

Meng, X. (1998). Gender occupational segregation and its impact on the gender wage differential among rural-urban migrants: a Chinese case Study. Applied Economics, 30(6), 741-752. 
E. Caroline, FX Sugiyanto, Achmad S. K, Etty P.L \& Ceacilia S. / INDICATORS Journal of Economics and Business Vol 1 (2) (2019)

Najia S. N., Maryam, M. \& Nabeel, R. (2013). Pakistan's FDI Impact of Foreign Direct Investment on Economic Growth of Pakistan. Advances in Management \& Applied Economics, 3(1), 35-45.

Victor, M. T. (2011). The impact of trade openness on foreign direct Investment. inflows in emerging market economies.

Yaseen, H. (2014). The Impact of Foreign Direct Investment FDI on Economic Growth of Jordan. European journal of bussines and Management, 6(1), 39. 